
M. B. СЕМЕНЮК ${ }^{3}$

К3 “Обласний перинатальний центр” Рівненської обласної ради ${ }^{1}$

ДВНЗ “Тернопільський державний медичний університет імені І. Я. Горбачевського МОЗ України”2

ТОВ "ЛОКЕ" Рівне

\title{
Особливості хірургічного лікування варикозного розширення вен пахового каналу у вагітних
}

\begin{abstract}
Мета роботи: розробка показань до операційного лікування пахового варикозу у вагітних та оцінка результатів лікування за умов короткочасного перебування в стаціонарі.

Матеріали і методи. На базі комунального закладу “Обласний перинатальний центр” Рівненської обласної ради з початку 2013 р. до лютого 2018 р. включно діагноз первинного симптомного варикозного розширення вен пахового каналу (ПСВРВПК) встановлено у 265 жінок. Ізольовану форму ПСВРВПК діагностовано у 68 (25,66 \%) вагітних, поєднані форми виявлено у 197 (74,34 \%) вагітних із венами басейну сафенових вен, зовнішніх статевих органів, промежини. У плановому порядку прооперовано 48 (18,11 \%) вагітних з симптомним ПСВРВПК у II-III триместрах вагітності.

Результати досліджень та їх обговорення. Розроблено і впроваджено тактику лікування даної патології залежно від форми та поширення. 48 (18,11 \%) пацієнток дали згоду на проведення в плановому порядку хірургічного лікування даної патології в II-III триместрах вагітності: 21 (43,75 \%) жінка через неефективну консервативну терапію, коли захворювання клінічно прогресувало і поширювалось; 18 (37,5 \%) вагітних з метою підготовки природного пологового шляху до пологів природним шляхом при вираженому варикозному розширенні вен зовнішніх статевих органів і промежини для зменшення ризиків кровотечі у випадку розриву варикозних вузлів та звуження показань до хірургічних пологів; 9 (18,75 \%) вагітним на їх вимогу, для покращення косметичних проблем зовнішніх статевих органів і/або нижніх кінцівок, спричинених варикозним розширенням вен при відсутності протипоказань до втручання у вагітної з боку соматичного і акушерського статусів.
\end{abstract}

Ключові слова: варикозне розширення вен пахового каналу; хірургічне лікування пахового варикозу в плановому порядку; дуплексне сканування вен.

Постановка проблеми і аналіз останніх досліджень та публікацій. Для широкого кола лікарів первинне симптомне варикозне розширення вен пахового каналу становить проблему, що рідко зустрічається і часто не діагностують в зв'язку 3 нетиповим розташуванням варикозних вен, скромністю жінок, а в деяких випадках через відсутність будь-яких проявів дискомфортних відчуттів у пацієнток $[1,4,6,8]$. Хоча дану проблему спостерігають майже у третини вагітних, важливо зазначити, що дана патологія супроводжує від 2 до $10 \%$ жіночого населення [4, 7]. Поява та можливості сучасної ультразвукової діагностики допомогли підійти до вирішення багатьох питань даної актуальної і значущої проблеми для вагітних жінок [10]. Проте лікування варикозного розширення вен пахового каналу, промежини, зовнішніх статевих органів, нижніх кінцівок або їх поєднанно під час вагітності $є$ однією із невирішених проблем та переважно залишаються недослідженими. Більшість акушер-гінекологів і судинних хірургів негативно ставиться до планового хірургічного лікування даної патології на тлі вагітності. Показане хірургічне лікування лише ускладнених форм даної патології і тільки в екстрених випадках. При цьому вирішується одне із головних питань: чи можливе виключення підшкірних вен промежини, зовнішніх статевих органів, нижніх кінцівок, пахового каналу або в поєднанні без виникнення i/ або наростання при цьому симптомів тазового венозного повнокрів'я. Звернено увагу на техніку виконання оперативного втручання при хірургічному лікуванні венозної патології в даних ділянках і зазначено, що доцільно виконувати флебектомію із окремих розрізів, не використовуючи мініфлебектомію, оскільки варикозні конгломерати тонкостінні і при їх незначній тракції травмуються зі значними кровотечами $[1,2,5]$. 3 урахуванням вищеперерахованого актуальними є дослідницькі роботи, спрямовані на досягнення максимального зменшення травматичності втручання, мінімізації проявів больового синдрому, що підвищує комфортність та безпечність від проведеного операційного лікування [9].

Мета роботи: розробка показань до операційного лікування пахового варикозу у вагітних та оцінка результатів лікування за умов короткочасного перебування в стаціонарі.

Матеріали і методи. На базі комунального закладу “Обласний перинатальний центр” Рівненської обласної ради з початку 2013 р. до лютого 
2018 р. включно діагноз первинного симптомного варикозного розширення вен пахового каналу (ПСВРВПК) встановлено у 265 жінок. Ізольовану форму ПСВРВПК діагностовано у 68 (25,66 \%) вагітних, поєднані форми виявлено у 197 (74,34%) вагітних із венами басейну сафенових вен, зовнішніх статевих органів, промежини. У плановому порядку прооперовано 48 (18,11 \%) вагітних із симптомним ПСВРВПК у II-III триместрах вагітності.

Відповідно до українського Консенсусу лікування пацієнтів із варикозною хворобою нижніх кінцівок (2005) для вагітних використали другий рівень діагностики - дуплексне скануванн, яке проводили за допомогою апарата LANWIND MIRROR II 3 лінійним датчиком частотою 8-10 MHZ у положенні лежачі і стоячи (ортостазі) згідно з розробленим нами протоколом. Даний метод не $є$ інвазивним, не спричиняє явних ятрогенних ускладнень як з боку вагітної, так і плода. Для безпечного проведення дослідження (запобігання аортокавальному синдрому, синдрому нижньої порожнистої вени) у 78 \% вагітних виконували в положенні лежачи на лівому боці під кутом 30 градусів. У вагітних дуплексне сканування виконували переважно (88 \% обстежених) у другій половині дня, коли наростають клінічні симптоми гемодинамічних порушень у венозній системі (відчуття тяжкості в нижніх кінцівках, промежині, набряки, парестезії) з використанням проби Вальсальви. Дані клінічного огляду пацієнток в 100 \% випадків підтверджені результатами дуплексного сканування.

Прицільно розпочали вивчення частоти і форм симптомного первинного варикозного розширення вен круглої зв'язки матки (СПВРВКЗМ), джерела його формування та їх участь у формуванні варикозного розширення вен зовнішніх статевих органів та нижніх кінцівок шляхом дуплексного сканування вен пахового каналу у вагітних пацієнток як $з$ ізольованою формою варикозного розширення вен пахового каналу, так і в поєднанні із варикозною хворобою нижніх кінцівок, промежини, зовнішніх статевих органів.

Вивчали можливий вплив даної венозної патології і хірургічного лікування її в плановому порядку на матково-плацентарний і кровотік у плода за допомогою УЗД дослідження в артеріях пуповини, маткових артеріях та середньомозковій артерії плода, а також серцеву діяльність плода і тонус матки у вагітних за допомогою даних кардіотокографії.

Результати досліджень та їх обговорення. Вирішенню тактики лікування даної патології передує колегіальне рішення акушер-гінеколога і су- динного хірурга після огляду вагітної, оцінки клінічних та інструментальних даних обстеження. Акушер-гінеколог проводить оцінку скарг, загального стану вагітної і плода, аналізуючи дані КТГ, фетометрії, зважує ризики впливу того чи іншого методу лікування на їх стан та вибір періоду, в який можливо найкраще виконувати той чи інший метод лікування. Флеболог обирає метод хірургічного втручання, знеболення і оцінює його можливості корекції венозної гемодинаміки з позитивним результатом втручання 3 мінімальним ризиком впливу запропонованого методу знеболення, об’єму хірургічної допомоги на матір і плід із коротким періодом післяопераційної реабілітації. Після чого колегіально формулюють тактику лікування (консервативна чи хірургічна) залежно від форм СПВРВПК. Сформульовану тактику лікування доводили до відома вагітної, роз'яснюючи суть кожного методу лікування, особливо суть хірургічної тактики, яка базується на наступних критеріях: запобігання прогресуванню захворювання, стабілізуючи його для коректного виношування вагітності; активна безмедикаментозна профілактика акушерським ускладненням (геморагіям, тромбемболіям, тромбофлебітам); підготовка пологових шляхів для проведення пологів природним шляхом запобігаючи геморагічним ускладненням із варикозних вузлів зовнішніх статевих органів промежини, звужуючи показання до пологів через кесарів розтин, покращення косметичних проблем за бажанням вагітної. Після цього рішення про лікування приймає самостійно вагітна.

Сформовано комплекс хірургічного втручання, в основу якого покладено недовготривалість оперативного втручання при незначній травматизації м'яких тканин кінцівки та пахової ділянки, тривалістю до 30 хв 3 можливістю ліквідації причин хвороби шляхом ліквідації зон рефлюксів, видаленням ділянок вен, уражених варикозним процесом зі збереженням неуражених, 3 короткотерміновою післяопераційною реабілітацію, яке виконується під тумінесцентною анастезією без введення агресивних препаратів тератогенної дії на плід, відсутність необхідності використання анастезіологічної допомоги великого об’єму, що покращує якість життя і запобігає ускладненням у вагітних із первинною симтоматичною варикозною хворобою.

Із 265 пацієнток із різними формами СПВРВКЗМ на оперативне лікування дали згоду 48 (18,11 \%) вагітних - $з$ ізольованою формою СПВРВКЗМ 9 (18,75 \%) вагітних; в поєднанні СПВРВКЗМ із прогресуючим варикозним розширенням вен нижніх кінцівок 19 (39,58 \%) пацієн- 
ток і 20 (41,67 \%) обстежуваних у поєднанні з варикозним розширенням сафенових вен та її гілок, вен зовнішніх статевих органів і промежини.

Показаннями для проведення хірургічного лікування в плановому порядку даної патології в IIIII триместрах серед 48 пацієнток вагітності: 21 (43,75 \%) пацієнтка через неефективну консервативну терапію, коли захворювання клінічно прогресувало і поширювалось; 18 (37,5 \%) вагітним 3 метою підготовки природного пологового шляху до пологів природним шляхом при вираженому варикозному розширенні вен зовнішніх статевих органів і промежини для зменшення ризиків кровотечі у випадку розриву варикозних вузлів та звуження показань до хірургічних пологів; 9 (18,75 \%) хворим - на їх вимогу для покращення косметичних проблем зовнішніх статевих органів i/або нижніх кінцівок, спричинених варикозним розширенням вен.

Операційне втручання виконували при відсутності протипоказань до втручання у вагітної з боку соматичного і акушерського статусів у вагітних у другій половині II і протягом III триместру вагітності в присутності анестезіолога без премедикації з розташуванням вагітних у 75 \% випадків на лівому боці або поворотом деки операційного столу під кутом в 15-30 градусів з метою запобігання розвитку в них синдрому нижньої порожнистої вени. Катетеризували ліктьову вену, виконували крапельну інфузію фізіологічного розчину. Як місцевий анестетик використовували розчин 0,15 \% новокаїну (мінімальна кількість 40 мл, максимальна - 120 мл).

Ми використовували таку розроблену нами тактику лікування: 1 варіант - 13 (4,9 \%) пацієнткам із клінічними проявами СПВРВКЗМ, який не виходив за його межі, підтвердженого дуплексним скануванням, проводили динамічне спостереження за пацієнткою з проведенням періодичного дуплексного сканування пахових каналів за клінічними показами. Рекомендуємо вагітним обмеження фізичних навантажень, носіння спеціальної білизни.

2 варіант - у 18 (37,5 \%) пацієнток з ізольованою формою СПВРВКЗМ, що вже вийшов за межі пахового каналу, сформував варикозне розширення вен зовнішніх статевих органів, грижоподібне випинання в ділянці зовнішнього пахового кільця, що обмежує носіння білизни, наростання болю в цих ділянках, особливо при справлянні фізіологічних потреб і фізичних навантаження, підтвердженого дуплексним скануванням, виконали під місцевим знеболенням (тумесцентна анестезія) перев'язку СПВРВКЗМ шляхом обшивання його в ділянці зовнішнього пахового кільця 2 лігату- рами без їх висічення із розрізу паралельного пупартовій зв'язці в проекції зовнішнього пахового кільця завдовжки до 3 см без розкриття пахового каналу. 7 пацієнткам перев’язування вен цієї локалізації виконали двобічно в одну сесію, а 11 - однобічно (рис. 1). Враховували особливості будови стінок вен СПВРВКЗМ у ділянці зовнішнього пахового кільця, нижніх кінцівках, зовнішніх статевих органів, промежини, які є тонкостінні, інтимно припаяні до навколишніх тканин, легко розриваються при їх незначній тракції, тому їх пошук і виділення в разі використання техніки мініфлебектомії утруднені. 3 огляду на це у всіх випадках використовували накладання лігатур шляхом обшивання варикозних конгломератів як мінімум 2 лігатурами із окремих розрізів без їх висічення.

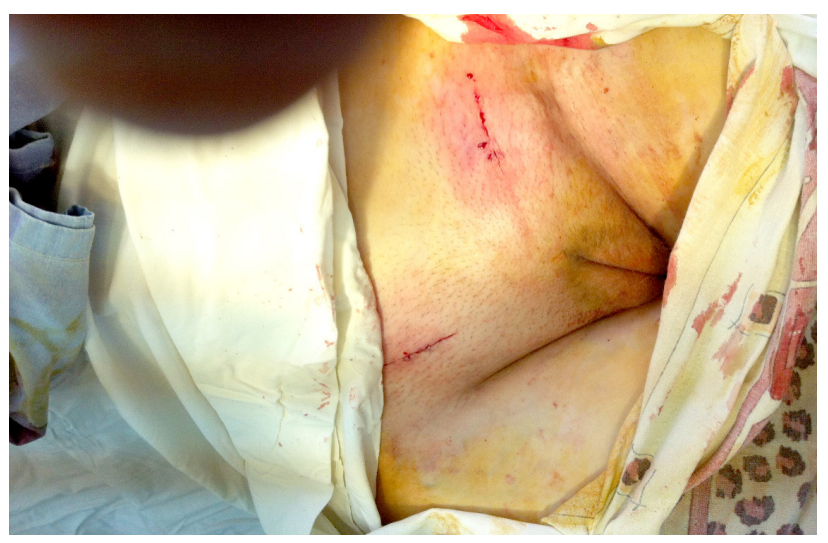

Рис. 1. Операційний доступ при ізольованій формі захворювання.

3 метою зменшення больового синдрому під час виділення венозного пучка в зовнішньому паховому кільці і його перев’язку необхідно звертати увагу на наявність кінцевої гілки nn.ilioinguinalis, ramus femoralis n. genitofemoralis по його нижній сфері.

3 варіант - $16(33,33)$ пацієнткам із поєднанними формами захворювання: СПВРВКЗМ із поширенням у зовнішні статеві органи та нижні кінцівки з варикозним розширенням сафенових вен із рефлюксом в зовнішню соромну вену, додаткову медіальну із проксимального відділу великої підшкірної вени з формуванням варикозного розширення вен зовнішніх статевих органів і промежини виконували в одну сесію перев'язування шляхом обшивання СПВРВКЗМ їі гілок без їх висічення в зовнішньому паховому кільці і проксимального відділу великої підшкірної вени та її гілок у ділянці підшкірно-стегнового злиття - із 2 окремих розрізів: один у проекції зовнішнього пахового кільця, другий в проекції підшкірно-стегнового з'єднання - модифікований розріз Черв'якова (рис. 2). 


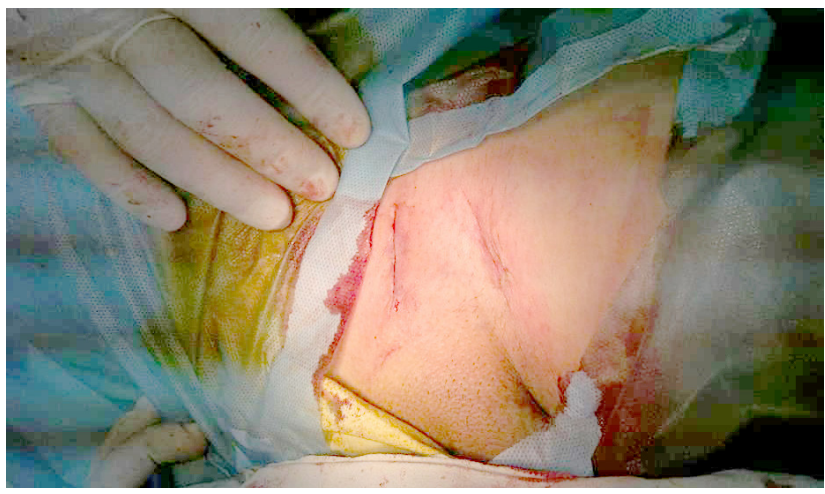

Рис. 2. Операційний доступ при поєднаній формі захворювання.

Операційні рани зашивали внутрішньодермально, проленовою ниткою.

Контроль за безпечністю оперативного втручання як для матері, так і плода проводили шляхом кардіотокографії, фетометрії до операції і після, оцінювали тонус матки, характеристику серцебиття плода та його рухи (кількісні та їх якість). Ускладнень соматичного і акушерського статусів із боку матері і плода не спостерігали як під час проведення тумесцентної анестезії, так і в післяопераційний період. Перебіг вагітності, розвиток дитини в післяопераційний період без особливостей. Під час оперативного втручання, в післяопераційний період у всіх оперованих вагітних змін тонусу матки, характеристик серцебиття і рухів плода не спостерігали, як за даними кадіотокографії, так і за суб'єктивною оцінкою вагітними власного стану та за характеристикою якості і кількості рухів плода, що вказувало на безпечність планового хірургічного лікування. У всіх оперованих у ранньому післяопераційному періоді отримано позитивний результат як за суб'єктивною оцінкою вагітними, так за даними інструментальних досліджень. В усіх оперованих пологи відбулися природним шляхом без геморагічних, тромбофлеботичних і тромбоемболічних ускладнень як під час виношування, пологів, так і в післяпологовий період. У післяопераційний період виконували контрольне дуплексне сканування з метою виявлення рефлюксів. За результатами виявлено їх відсутність, оскільки вони перев’язані, появи нових не встановлено (рис. 3, 4).

Вагітних, оперованих у II триместрі і на початку III триместру, виписали на 2 день після операції під нагляд лікаря-акушера за місцем проживання. Пацієнтки, прооперовані в кінці III триместру, перебували в стаціонарі до пологів. Фізичні навантаження рекомендовані в повному об'ємі по можливості всім пацієнткам. Антибіотики, венотоніки, дезагреганти в післяопераційний період не призначали. Усім вагітним рекомендоване носіння еластичного трикотажу (панчіх) клас комп-

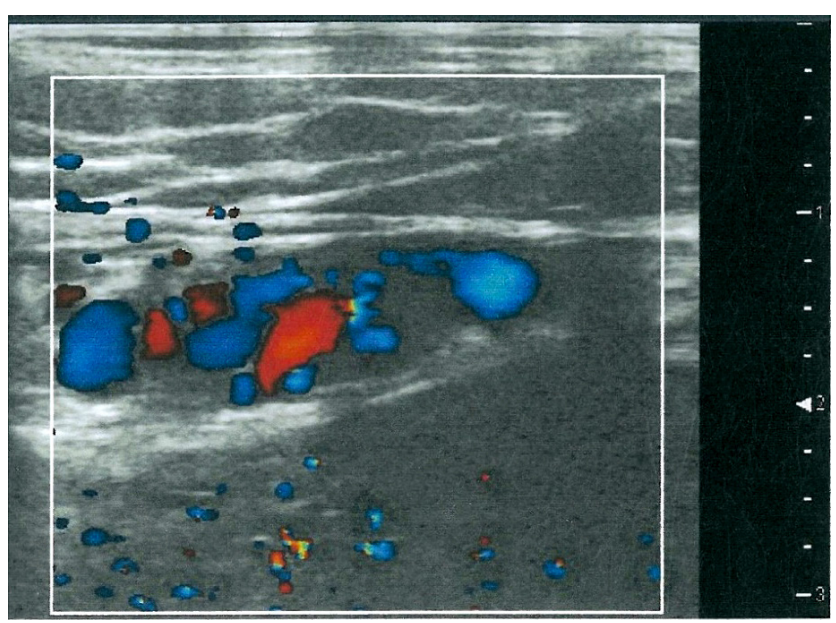

Рис. 3. УЗД вен пахового каналу до операції.

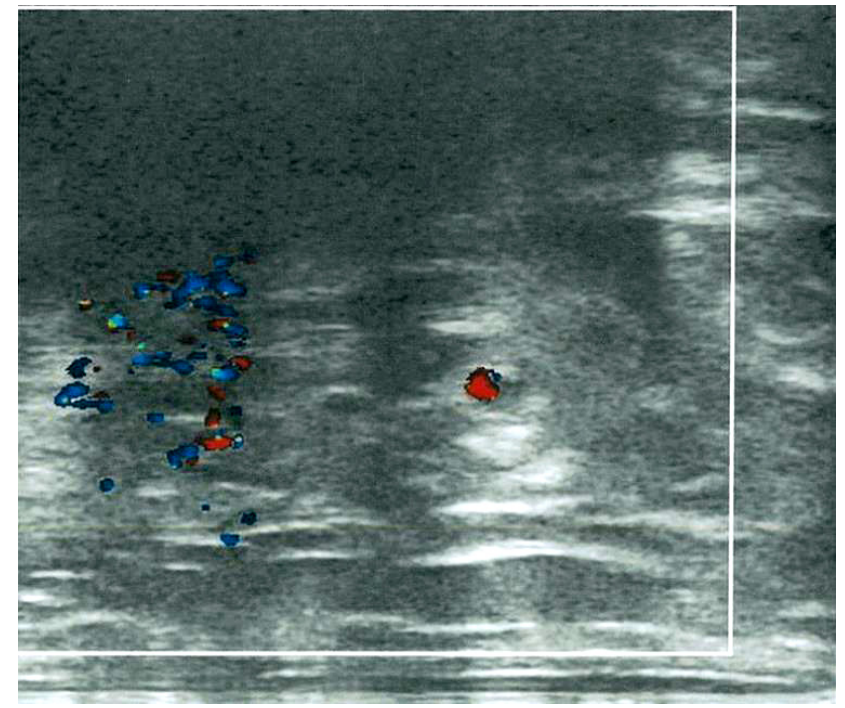

Рис. 4. УЗД вен пахового каналу через 48 год після операції.

ресії 2. Знеболювальні препарати в післяопераційний період в таблетованній формі призначали 25 \% оперованих вагітних протягом перших годин.

Висновки. 1. Під час вагітності хірургічне лікування різних форм СПВРВКЗМ виконували в плановому порядку 18,11 \% вагітних у випадках неефективної консервативної терапії, коли захворювання клінічно прогресувало та при відсутності протипоказань до втручання у вагітної з боку соматичного і акушерського статусів. При ізольованій формі СПВРВКЗМ, коли варикозне поширення виходило за межі пахового каналу, клінічно проявляючись варикозним розширенням вен зовнішніх статевих органів i/або нижніх кінцівок, накладались лігатури шляхом обшивання без висічення варикозних конгломератів і вен, що виходять із зовнішнього пахового кільця без розкриття пахового каналу. 
2. При поєднанні СПВРВКЗМ, які є причиною варикозного розширенням вен зовнішніх статевих органів, нижніх кінцівок і варикозного розширення зовнішніх статевих органів, виконували в одну сесію перев’язування вен і варикозних конгломератів шляхом накладання лігатур і обшиванням їх із шовного матеріалу, що не розсмоктуються, на вени, що виходять із зовнішнього пахового кільця без розкриття пахового каналу і на стовбури сафенових вен у ділянці співусть і на їхні гілки.

\section{СПИСОК ЛІТЕРАТУРИ}

1. Гаврилов С. Г. Варикозная болезнь вен малого таза: современное состояние проблемы / С. Г. Гаврилов, О. И. Бутенко, М. А. Черкашина // Анналы хирургии. -2003.- № 1. - С. 7-12. 2. Гаврилов С. Г.Тактика лечения больных сочетанной варикозной болезнью вен таза и нижних конечностей / С. Г. Гаврилов, А. В. Сажин, М. Д. Темирболатов // Флебология.2017. № 11(3). - С. 120-130.

3. Изолированные хирургические вмешательства на подкожных венах при варикозной болезни вен таза / С. Г. Гаврилов, А. В. Каралкин, В. Е. Васильев [и др.] // Флебология. 2012. - № 6 (2). - С. 9-13.

4. Особенности клинического течения беременности и родов у женщин с варикозом вульв, влагалища и промежности / Ю. Т. Цуканов, Е. Н. Кравченко, И. А. Криворотов [и др.] // Флебология. - 2013. - № 2. - С. 21-25.

5. Суковатых Б. С. Патогенетическое обоснование миниинвазивного лечения варикозной болезни вен малого таза /

\section{REFERENCES}

1. Gavrilov, S.G., Butenko, O.I., \& Cherkashina, M.A. (2003). Varikoznaya bolezn ven malogo taza: sovremennoye sostoyanie problemy [Varicose veins of the small pelvis: the current state of the problem]. Annaly khirurgii - Annals of Surgery, 1, 7-12 [in Russian]. 2. Gavrilov, S.G., Sazhin, A.V., \& Temirbolatov, M.D. (2017). Taktika lecheniya bolnykh sochetannoy varikoznoy boleznyu ven taza i nizhnikh konechnostey [Tactics of treatment of patients with concomitant varicose veins of the pelvic and lower extremities]. Flebologiya - Phlebology, 11 (3); 20-130 [in Russian]. DOI: 1017116/flebo2017113120-130(http://dx.doi.org/10.17116/ flebo2017113120-130.

3. Gavrilov, S.G., Karalkin, A.V., \& Vasilyev, V.E. (2012). Izolirovanyye khirurgichiskie vmeshatelstva na podkozhnykh venakh pri varikoznoy bolezni ven taza [Isolated surgical interventions on the subcutaneous veins in varicose veins of the pelvis]. Flebologiya - Phlebology, 6 (2), 9-13 [in Russian].

4. Tsukanov, Yu.T., Kravchenko, E.N., Krivorotov, I.A. (2013). Osobennosti klinicheskogo techeniya beremenosti i rodov u zhenshchin s varikozom vulv, vlagalishcha i promezhnosti [Features of the clinical course of pregnancy and childbirth in women with varicose veins of vulva, vagina and perineum]. Flebologiya -
Перспективи подальших досліджень. Перспективним є подальше дослідження даної патології, яка трапляється не так уже і рідко, для акушерської практики і практики загальних хірургів для розуміння причини болю в пахових ділянках, особливо у вагітних, трактування грижоподібних випинань у даних ділянках, у диференційній діагностиці пахових або стегнових кил, гематом пахових каналів при розриві вен пахового каналу під час переймів.

Б. С. Суковатых, М. Б. Суковатых // Новости хирургии. 2012.- T. 20, № 1. - С. 54-61.

6. A diagnostic dilemma: round ligament varicosities in pregnancy / C. Chi, A. Taylor, N. Munjuluri [et al.] // Acta Obstet. Gynecol. Scand. - 2005. - Vol. 8. P. - P. 1126-1127.

7. Einarsson E. Sclerography or surgery as treatment for varicose veins: a prospective randomized study / E. Einarsson, B. Elkoff, P. Neglen // Phebology. - 1993. - Vol. 8. - P. 22-26.

8. Bilateral round ligament varicosities mimicring inguinal hernia during pregnancy / F. F. Ijpma, K. M. Boddeus, H. H. deHaan [et al.] // Hernia. - 2009. - Vol. 13. - P. 85-88.

9. Lafrati M. D. Subfascial endoscopic perforator ligation: An fanalysis of early clinical outcomes and cost / M. D. Lafrati, H. J. Welch, T. F. O’Donnenell // J. Vase. Surg. -1998. - Vol. 26. - P. 991-995.

10. Round ligament varices:sonographic appearance in pregnancy / D. A. McKenn, J. T. Carter, L. Poder [et al.] // Ultrasound Obstet. Gynecol. - 2008. - Vol. 31. - P. 355-357.

Phlebology, 2, 21-25 [in Russian].

5. Sukovatykh, B.S., \& Sukovatykh, M.B. (2012). Patogeneticheskoe obosnovaniye mini invasivnogo lecheniya varikoznoy bolezni ven malogo taza [Pathogenetic substantiation of mini-invasive treatment of varicose veins of small pelvis]. Novosti khirurgii - News of Surgery, 20 (1), 54-61 [in Russian].

6. Chi, C.A., Taylor, A., \& Munjuluri, N. (2005). Diagnostic dilemma: round ligament varicosities in pregnancy. Acta Obstet. Gynecol. Scand., 8, 1126-1127.

7. Einarsson, E., Elkoff, B., \& Neglen, P. (1993). Sclerography or surgery as treatment for varicose veins: a prospective randomized study. Phebology, 8, 22-26.

8. Ijpma, F.F., Boddeus, K.M., \& de Haan, H.H. (2009). Bilateral round ligament varicosities mimicking inguinal hernia during pregnancy. Hernia, 13, 85-88.

9. Lafrati, M.D., Welch, H.J., \& Donnenell, T.F.O. (1998). Subfascial endoscopic perforator ligation: An fanalysis of early clinical outcomes and cost. J. Vasc. Surg., 26, 991-995.

10. McKenna, D.A., Carter, J.T., \& Poder, L. (2008). Round ligament varices: sonographic appearance in pregnancy. Ultrasound Obstet. Gynecol., 31, 355-357. 
Regional Perinatal Center of Rivne Regional Counsil ${ }^{1}$ I. Horbachevsky Ternopil State Medical University ${ }^{2}$

Loke Ltd., Rivne ${ }^{3}$

\title{
FEATURES OF SURGICAL TREATMENT OF VARICOSE VEINS OF THE INGUINAL CANAL IN PREGNANT WOMEN
}

\begin{abstract}
The aim of the work: development of indications for surgical treatment of inguinal varicose veins in pregnant women and evaluation of treatment results in conditions of short-term stay in a hospital.

Materials and Methods. On the basis of the communal facility "Regional Perinatal Center" of the Rivne Regional Council from the beginning of 2013 to February 2018, including the diagnosis of primary symptomatic varicose veins of the inguinal canal (PSVVIC) was established in 265 women. Isolated form of PSVVIC was diagnosed in 68 (25.66 \%) pregnant women, combined forms were found in 197 (74.34 \%) of pregnant women with veins in the basin of saphen veins, external genital organs, perineum. In the planned order, 48 (18.11 \%) pregnant women with symptom of the PSVVIC in II-III trimesters of pregnancy were operated.

Results and Discussion. The tactics of treatment of this pathology, depending on the form and distribution, have been developed and implemented. 48 (18.11\%) patients agreed to conduct surgical treatment of this pathology in the 2nd-3rd trimester of pregnancy: 21 (43.75\%) of women due to ineffective conservative therapy when the disease progressed clinically and spread; 18 (37.5\%) pregnant women for the purpose of preparing the natural birth line for delivery by natural means, with pronounced varicose veins of the external genitalia and perineum to reduce the risk of bleeding in the event of rupture of varicose nodes and narrowing of indications for surgical delivery; 9 (18.75\%) pregnant at their request to improve the cosmetic problems of the external genital organs and / or lower extremities caused by varicose veins in the absence of contraindications for intervention in the pregnant woman from the somatic and obstetric status.
\end{abstract}

Key words: varicose veins of the inguinal canal; surgical treatment of inguinal varices in a planned manner; duplex scan of veins.

\author{
В. Н. АНТОНЮК-КИСЕЛЬ ${ }^{1}$, И. Я. ДЗЮБАНОВСКИЙ ${ }^{2}$, В. Н. ЕНИКЕЕВА ${ }^{1}$, С. И. ЛИЧНЕР ${ }^{1}$, В. М. ЛИПНЫЙ \\ Н. В. СЕМЕНЮК ${ }^{3}$ \\ КУ “Областной перинатальный центр” Ровенского областного совета ${ }^{1}$ \\ гВУЗ “Тернопольский государственный медицинский университет имени И. Я. Горбачевского МЗ Украины"2 \\ ООО "ЛОКЕ" РОВНО
}

\section{ОСОБЕННОСТИ ХИРУРГИЧЕСКОГО ЛЕЧЕНИЯ ВАРИКОЗНОГО РАСІІРЕНИЯ ВЕН ПАХОВОГО КАНАЛА У БЕРЕМЕННЫХ}

Цель работы: разработка показаний к операционному лечению пахового варикоза у беременных и оценка результатов его лечения в условиях кратковременного пребывания в стационаре.

Материалы и методы. На базе коммунального учреждения “Областной перинатальный центр” Ровенского областного совета с начала 2013 г. по февраль 2018 г. включительно диагноз первичного симптомного варикозного расширения вен пахового канала (ПСВРВПК) установлен в 265 женщин. Изолированную форму ПСВРВПК диагностировано у 68 (25,66 \%) беременных, сочетанные формы обнаружены в 197 (74,34 \%) беременных с венами бассейна сафенных вен, наружных половых органов, промежности. В плановом порядке прооперировано 48 (18,11\%) беременных с симптомним ПСВРВПК во II-III триместрах беременности.

Результаты исследований и их обсуждение. Разработано и внедрено тактику лечения данной патологии в зависимости от формы и распространения. 48 (18,11\%) пациенток дали согласие на проведение в плановом порядке хирургического лечения данной патологии во II-III триместрах беременности: 21 (43,75 \%) женщина из-за неэффективной консервативной терапии, когда заболевание клинически прогрессировало и распространялось; 18 (37,5 \%) беременных с целью подготовки природного родильного пути к родам естественным путем при выраженном варикозном расширении вен наружных половых органов и промежности для уменьшения рисков кровотечения в случае разрыва варикозных узлов и сужения показаний к хирургическому родоразрешению; 9 (18,75 \%) беременным по их требованию, для улучшения косметических проблем наружных половых органов и/ или нижних конечностей, вызванных варикозным расширением вен при отсутствии противопоказаний к вмешательству в беременной со стороны соматического и акушерского статуса.

Ключевые слова: варикозное расширение вен пахового канала; хирургическое лечение пахового варикоза в плановом порядке; дуплексное сканирование вен. 